\title{
Development Literacy Based on the Neuroscience Theory for Early Childhood in Digital Era
}

\author{
Yaswinda, Yulsyofriend \\ PG PAUD Universitas Negeri Padang, Indonesia \\ e-mail: yaswinda@ fip.unp.ac.id
}

\begin{abstract}
This research is interested in implying the theory of neuroscience in the development of early childhood literacy. However, in this paper, the author only draws on the results of preliminary research on the current state of developing listening literacy in the Kuranji sub-district, Padang, Indonesia. This research is part of research and development which consists of 10 stages using a combination of Borg and Gall (1983). This research can be summarized as follows: (1) Preparation of listening learning literacy planning gets a score 95\% which means high category; (2) The learning process of listening literacy gets a score $95 \%$ which means high category; (3) The importance of socializing the use of media devices that combine traditional tools and digital technology.
\end{abstract}

Keywords: Literacy development, early childhood, neuroscience theory, digital era

\section{INTRODUCTION}

In the digital era, literacy skill still a very important role to be developed for early childhood. The use of digital technology devices can greatly help bring about early literacy. According to Cowen and Cohen (2011) the role of teachers and parents is very necessary to develop early childhood liability skills by combining the use of traditional equipment such as using a pencil with the use of technology tools such as tablets. According to Neuman and Neuman (2013), this approach will empower children to grow into effective readers their writers to participate actively and successfully in technologically advanced societies. But the optimal use of tablets for early childhood learning depends on the availability of quality applications at home and in a preschool environment (Orrin and Olcese, 2011). The use of digital technology in early childhood is re-conceptualized from early childhood learning in early childhood early childhood pedagogy and settings when children under five are involved with digital technology in playing and learning at home and in kindergarten (Palaiologou, 2014) . Listening is part of the acceptance of language, but the ability to listen to early childhood is very little considered in kindergarten (Doludeal and Nuraeni, 2018). Listening skills which is a process that includes listening to language, identifying, interpreting, evaluating, and reacting to the meaning contained therein (Resmini \& Djuanda, 2007; Tarigan, 1986). The ability to listen is very important for every child, because every activity carried out in daily life is related to listening ability. Listening to the words of others is one of the ways children receive language that requires the ability to store various information and is related to the thinking process. The ability to listen well and correctly is a capital for children to live in the future (Sutanto, 2014). Neuroscience comes from psychology, neurology, biology, and physiology and is sometimes called brain science. With the help of high technology brain imaging technology, neurologists around the world make unprecedented 
breakthroughs in understanding the role of experience in human development (Frost, Worthamm, and Reifel, 2012). The development of the human brain generally follows the development of its biological age. The physical growth of the brain reaches $50 \%$ at the age of 2 years, and $90 \%$ at the age of 6 years, and achieves optimal growth $(100 \%)$ at the age of 12 years. Intellectual development of the brain reaches $50 \%$ at the age of 4 years, then at the age of 8 years children's intellectual development reaches $80 \%$. The optimal condition of intellectual development is reached at the age of 18 years. The physical growth of the brain and the development of child intelligence is very rapid at the age of 0-8 years (golden age) because at this time it is very important for us to stimulate the brain until the optimal condition of the brain can be achieved (Jamaris, 2013). The agreement between neurologists is that the characteristics of almost all brain systems, including language, hearing, visual, and attention, are shaped by experience (Frost, Worthamm, and Reifel, 2012). In line with this theory, Vygotsky assumes that human behavior is mediated by cultural tools to act on the environment and physical devices, which are used for thinking. Language is an example of a tool used as planning, remembering, forming conceptual problems and regulating behavior (Siegler and Alibali, 2005). Vygotsky's theory places much emphasis on effective social interaction. Vygotsky believes that mental, language and social development is supported and enhanced through interaction with others. The learning process can only occur when children interact and cooperate with the surrounding environment (Morrison). Listening skills can be related to information storage systems that involve the work of the child's brain. The brain works with two important principles. First, the principle of synergy. In a synergy system, the total amount is greater than the number of parts. For example the relationship of one person to another, not only will produce two versions of the story, but can be thousands or millions of versions. Second, the principle of repetition. The better practice of memory usage, the more relationships are made in the brain and the easier it is to remember something (Buzan, 2005).

Difficulties in remembering are difficulties in storing various information received by the five senses at the center of the nervous system that functions to regulate memory and memory. Greenspan and Wieder explained that the growth and development of children in general includes three major areas in the central nervous system that will affect human ability in the use of their senses in receiving, understanding and responding to information from the environment, namely sensory systems, processing systems, and motor systems. The three systems will function well and influence each other by functioning the five senses (Jamaris, 2013). If it is related to a growing issue about child development in the 21 st century that: (1) child development rests on social and cultural backgrounds globally all the time and place; (2) children as meaning makers and active learners; (3) learning in the context of family, group, community culture; (4). represent the world; (5) the role of understanding, identity, race and gender; (6) to understand science and technology; (7) implications of neuroscience (Smidt, 2013). Referring to this, this research is interested in implying the theory of neuroscience in the development of early childhood literacy. However, in this paper, the author only draws on the results of preliminary research on the current state of developing listening literacy in the Kuranji sub-district, Padang, Indonesia.

\section{METHOD}

This research is part of research and development which consists of 10 stages using a combination of Borg and Gall (1983); Borg, Gall and Gall (2007). In the first phase, a preliminary study was conducted to determine the state of listening literacy development carried out in many kindergartens in Kuranji sub-district. The questionnaire was designed to be completed by the head of the kindergarten and kindergarten teacher. After the questionnaire analysis, a series of interviews and then observations on 3 selected TKs representing the group category. But in this paper, only limited to submitting the results of the TK head questionnaire. This study uses a quantitative approach with survey methods. The study population was the head of kindergarten in Kuranji Subdistrict, Padang City, Indonesia, amounting to 34 people. But the data that can be used in this study is 30 heads of TK. The study was conducted in July 2018. The data obtained were then analyzed using simple statistical tests. 


\section{RESULT AND DISCUSSION}

Preliminary research results from the study of literacy development for early childhood by applying the neuroscience theory are included in figure 1 until figure 5

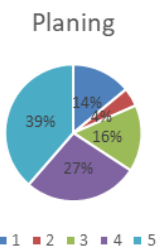

Fig.1. Planing development literates Information

$5=$ percentage of answers from respondents who answered always $4=$ percentage of respondent's answers that answer frequently

3 = percentage of answers from respondents who answer sometimes 2 = percentage of answers from respondents who answer rarely 1 = percentage of answers from respondents who answered never.

The total score obtained for this planning $95 \%$ means that it is included in the high category.

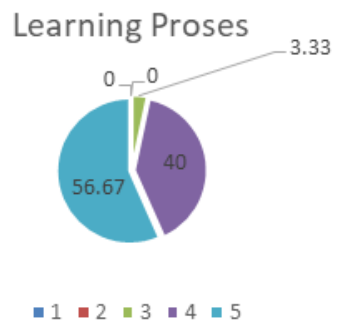

Fig. 2. Learning Proses development literates

\section{Information}

$5=$ percentage of answers from respondents who answered always $4=$ percentage of respondent's answers that answer frequently

3 = percentage of answers from respondents who answer sometimes $2=$ percentage of answers from respondents who answer rarely 1 = percentage of answers from respondents who answered never

The total score obtained for this planning 95\% means that it is included in the high category.
Method

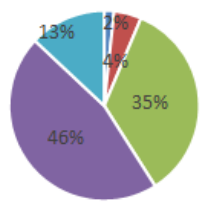

- $1.2=3: 4=5$

Fig. 3. Method development literates

Information

$5=$ percentage of answers from respondents who answered always $4=$ percentage of respondent's answers that answer frequently

3 = percentage of answers from respondents who answer sometimes 2 = percentage of answers from respondents who answer rarely 1 = percentage of answers from respondents who answered never

\section{Media}

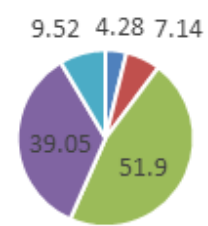

=1 $=2\|3=4\| 5$

Fig. 4. Media that uses for development literates

Information

$5=$ percentage of answers from respondents who answered always $4=$ percentage of respondent's answers that answer frequently

3 = percentage of answers from respondents who answer sometimes $2=$ percentage of answers from respondents who answer rarely $1=$ percentage of answers from respondents who answered never

The importance of socializing the use of media devices that combine traditional tools such as story books, series drawings and puppets and digital technology devices such as the use of interactive CD media and flash videos that support the development of early childhood listening literacy skills. 


\section{Evaluation}

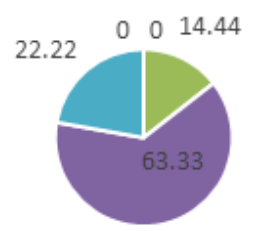

" $1=2 \| 3=4=5$

Fig. 5. Evaluation development literates

Information

$5=$ percentage of answers from respondents who answered

always

$4=$ percentage of respondent's answers that answer frequently

3 = percentage of answers from respondents who answer

sometimes

2 = percentage of answers from respondents who answer rarely $1=$ percentage of answers from respondents who answered never.

Difficulty in remembering is the difficulty in storing information received by the five senses at the center of the nervous system that functions to regulate memory. If the process of receiving information from the five senses goes well, then the information can be remembered and stored in the knowledge structure that exists in individual memory (Jamaris, 2013).

\section{CONCLUSION}

This research can be summarized as follows: (1) Preparation of listening learning literacy planning gets a score $95 \%$ which means high category; (2) The learning process of listening literacy gets a score $95 \%$ which means high category; (3) The importance of socializing the use of media devices that combine traditional tools and digital technology. Based on the conclusions of the study, it can be suggested for further research on the development of literacy listening to early childhood in kindergarten is the importance of socializing the use of media devices that combine traditional devices such as and digital technology devices such as the use of interactive $\mathrm{CD}$ media that supports the development of early childhood literacy skills in kindergarten.

\section{ACKNOWLEDGEMENTS}

In this moment I would like to thanks to Universitas Negeri Padang, for financial support from the LP2M Universitas Negeri Padang very helpful publication of this articlent.

\section{REFERENCES}

[1] Resmini, N., Hartati, T. \& Cahyani, I. (2009). Pembinaan dan pengembangan pembelajaran bahasa dan sastra Indonesia. Bandung: UPI Press

[2] Tarigan, H.G. 1986. Menyimak Sebagai Suatu Keterampilan Berbahasa. Bandung: Angkasa Press.

[3] Neumann, M.M. and Neumann, D.L. Touch Screen Tablets and Emergent Literacy. Early Childhood Educ J (2014) 42:231-239

[4] Susanto, Ahmad. 2014. Perkembangan Anak Usia Dini: Pengantar Dalam Perkembangan. Jakarta: Kencana Prenada Media.

[5] Cohen, V. L., \& Cowen, J. E. (2011). Literacy for children in an information age: Teaching reading, writing, and thinking. Belmont, CA: Wadsworth Cengage Learning

[6] Orrin, M. T., \& Olcese, N. R. (2011). Teaching and learning with iPads, ready or not? Techtrends, 55, 42-48.

[7] Frost, J.L. , Worthamm, S.C. and Reifel, S. (2012) Play and Child Development. Boston: Colombos Indianapolis New

[8] Jamaris, M. (2013) Orientasi Baru dalam Psikologi Pendidikan, Edisi Kedua. Bogor: Ghalia Indonesia.

[9] Morrison, G.S. (2011). Dasar-Dasar Pendidikan Anak Usia Dini (PAUD). Edisi kelima. Jakarta: Indeks

[10] Buzan, T. (2005) . The Ultimate Book of Mind Map. Jakarta: Harper Collins.

[11] Smidt, S. (2013). The Developing Child in the 21st Century, A global Perspective on Child Development, Second Edition. London: Routledge

[12] Palaiologou. I. (2016) Children under five and digital technologies: implications for early years pedagogy. European Early Childhood Education Research Journal. Volume 24, (1), 5-24

[13] Robert S. Siegler and Martha Wagner Alibali, Children's Thinking, Fourth Edition, (New Jersey: Pearson, 2005), h.138. 